2020, Volume 14, International Conference Innovative Business Management \& Global Entrepreneurship (IBMAGE 2020), pages: 538-552 I https://doi.org/10.18662/lumproc/ibmage2020/39

\section{Urban Regeneration and Its Challenges in Romania}

\section{Anna Maria VASILE1}

${ }^{1} \mathrm{PhD}$., National Institute for Economic Research "Costin C. Kiritescu” (INCE), Romanian Academy, Bucharest, Romania, anna.vasile@mail.com
Abstract: Urban regeneration defines the actions to convert old areas into new functional and spatial sustainable forms by attracting new activities, new commerce's, renovate urban infrastructure, upgrade the urban environment and transform the social structure [9].

The integrated urban regeneration operation involves an intervention at the urban level that intend according to the Toledo Declaration on Urban Development, to optimize, conserve and revalue the entire existing urban capital (social, built environment, heritage, etc.), compared to other forms of intervention in which, in all this urban capital, only the value of the land is prioritized and preserved by traumatic demolition and by replacing the entire urban and - most lamentably - social capital [11].

In order to be able to develop the studied area from all points of view, efforts must be made on all levels on which it has been agreed to implement actions, in order to achieve the proposed results.

Thus, in order to be able to develop the area economically, efforts must be made to adapt the commercial facilities for the new population concentrations. The authors defined in the paper, the concept of commercial urbanism which means all the efforts and means put in place by architects, urban planners, economists to adapt trade to new living conditions, new concentrations of population.

Keywords: public policies for urban regeneration; economic development; integrated development for $S M E^{\prime}$ s.

How to cite: Vasile, A.M. (2020). Urban Regeneration and Its Challenges in Romania. In M. W. Staniewski, V. Vasile, \& A. Grigorescu (vol. ed.), Lumen Proceedings: Vol. 14. International Conference Innovative Business Management \& Global Entrepreneurship (IBMAGE 2020) (pp. 538-552). Iasi, Romania: LUMEN Publishing House. https://doi.org/10.18662/lumproc/ibmage2020/39 


\section{Introduction}

Although apparently the concept of urban regeneration has become relatively familiar both in the regulations and in the programmatic documents of the Member States of the European Union, its practical connotations sometimes differ substantially from one country to another, mainly due to specific administrative-territorial organization conditions of the relations between the central and local level of the public administration institutions, the regulatory framework in the field of property, patrimony, education, social protection, environment etc.

Any modern urban community must assimilate and promote a strategic vision for its future development. The shortcoming is that it can create a chaotic administration, given that it is possible to offer a rate of opportunities and be consumed in terms of valuable resources [10].

Development projects and programs work best when they are part of a coherent framework and when there is thorough coordination at the strategic level.

The local public administrative mission is offered by quality public services to the citizens of the sector by improving the management in the administration of the sector and for the development of the economic-social space.

The social partnership is the interweaving of the will of the local community with the structures of the local administration, a way of working that its needed to be implemented in order to dynamize the local activity and the participation of the community; the participation of the local authority in assuming the responsibilities in order to face them both from a managerial, institutional, financial point of view.

In Romania there is a need to intensify the efforts to accelerate the activities to be able to reach its objectives, and to conjoin its achievements to Europe's developing Strategy [10].

Blending the dialogue between national, regional and local authorities will allow for a better promotion of EU priorities among citizens, mobilizing them to get involved and contribute to achieving the objectives aims.

In many European countries, regional or local authorities are responsible for the policy areas covered by the Europe 2020 Strategy, including education and training, entrepreneurship, the labour market or infrastructure.

It is essential that all levels of government are aware of the importance of the effective implementation of the Europe's Strategy and that each of them 
acts to make the necessary changes to promote smart, sustainable and inclusive growth.

\section{Problem Statement}

An analysis of the genesis in the scientific literature of the concept of urban regeneration and the evolution over time of the content of this concept, a review of its scope and the degree of transposition into European and Romanian legislation and practice, will help identifying the problems to solve.

The progress of the society was determined by discoveries, inventions and innovations, by social movements and revolutions, which favoured qualitative leaps and which opened new eras.

The city, over time, had a dynamic development, the development of production methods in agriculture and industry and means of transport have had the effect of depopulating rural settlements and increasing the population of cities and accentuating the redistribution of the population in the territory in favour of urban settlements.

Barosio, Eynard, Marietta, Marra, et al., in their paper, "From urban renewal to urban regeneration: Classification criteria for urban interventions. Turin 1995-2015: evolution of planning tools and approaches, cities faced complex challenges", concluded that the urban challenges were caused by the physical degradation of the heritage, the environment, transport etc. In their opinion, solving these problems requires a gradual change in methods of analysis and the need for new tools for transforming and managing the city [4].

Unlike urban renewal in contrast to urban degradation, urban regeneration processes encourage new urban development.

Thus, urban management is no longer focused on urban expansion and new development, but on the process of urban regeneration governance and related planning tools such as integrated programs. Therefore, it is important to agree on the exact meaning of urban regeneration.

As Peter Roberts et al specify in their paper "Urban Regeneration", this is a phenomenon with extensive experience, but little understood, needing new perspectives and inspiration to be based on both theory and practice. Moreover, he mentions that there is no clear form that can be put into practice and no single explanation is necessary to analyse the studied urban situation and implicitly there are no single appropriate solutions. Thus, it can be concluded that the process of urban regeneration must reflect the local particularities that define the city' [7].

As the authors point out, there is no universal or "single" solution to the problems identified in urban areas, which can be solved by taking into 
account local geography, economics, politics and history, which determine the actions to be taken to ensure efficient regeneration process that ensures lasting effects.

We can conclude that the need for urban regeneration must be seen as a continuous process, so an urban regeneration process must be thought of in the long run, even over several generations (or mandates). Consequently, permanent solutions cannot be applied, given that each generation (mandate) has its own priorities, look at the problems of the studied area from a certain angle, or have their own capacity of available resources.

Like Peter Roberts et al., Mariana Nae believes that urban regeneration can be interpreted in a holistic way, in full convergence with contemporary urban transformations. And she considers that the ordeal of urban regeneration is a complex one and not an isolated one, having an important role in (re) constructing the urban image [6].

According to the author, urban regeneration involves, in particular, the revaluation and reconversion of abandoned industrial areas, recreating a pleasant and attractive physical environment, thus restoring their positive image, to attract residents and new activities.

The same vision on this process is presented by the authors Maria Moldoveanu and Valeriu-Ioan Franc, who consider exactly that urban regeneration means, on the one hand, creative (smart) interventions in the existing built environment - as a premise for sustainable development and conservation of values and, on the other hand, the diversification of commercial, industrial or public service areas to be used as "unconventional spaces" for cultural creation and production [5].

As specified in the paper, the old buildings that themselves have a historical or aesthetic reputation with architectural value or not, of course, within their walls, is history. Thus, (re) conversion may involve the restoration of older or newer buildings, but it must be functional.

Cristina Alpopi and Cristina Manole, in their paper, "Integrated Urban Regeneration - Solution for Cities Revitalize", consider that the implementation of the interventions must take into account the city, on a process focused on solving the important problems of the city, which will benefit both the current population and the future [1].

Thus, in line with the ideas promoted by Roberts and Skyes, in 2000, the urban regeneration action is to find solutions to solve identified urban problems and find a long-term improvement of economic, physical, social and environmental aspects of the area studied [7].

This paper, will show that the local identity has a great importance to define the local image and thus to design the bases of the local culture, to be defined within a well-defined territory. Thus, defining a clear territorial context 
that determines the structure of urban entities, it will develop in accordance with the local public policies to be defined, including cultural and socioeconomic ones.

\section{Research Questions/Aims of the research}

This paper intends to show that the only way to ensure the success of urban regeneration projects and to provide support for sustainable urban development is an integrated approach to economic, social, demographic and environmental challenges.

In order to fulfil the desideratum of sustainable development through the urban regeneration of an area, a city, a municipality, it is necessary to identify the pillars on which the existence and evolution of the local community are based and which can ensure the process of urban regeneration and thus a sustainable development.

It is easy to see that the economic, social, demographic and environmental challenges facing cities are closely interdependent, with the integrated approach to planning being mandatory for the success of urban regeneration projects, all the more so in the context of achieving the objectives. sustainable development.

In conclusion, sustainable development needs to be based on an integrated approach to local community issues.

The spatial organization of the city's resources, the relations between the urban infrastructure and them, are very important in the cities development and thus the promotion of an economic growth of the area through the local development.

Urban regeneration for developed or developing countries has become a necessity due to strong competition between the world's cities. Culture can be used as a successful tool in the process of urban regeneration by gaining new, competitive advantages, which are based on the unique features of the city in question.

This paper is aiming to show that the increasing the number of tourist in an regenerated area, and will analyse the impact of the quality of road transport infrastructure, expressed by the percentage of modernized roads $(\mathrm{X} 1 \mathrm{t})$ and the degree of urbanization $(\mathrm{X} 2 \mathrm{t})$, expressed as a ratio between the urban population and the rural population, on the development of tourism in Romania. The degree of tourism development was analysed in the light of the evolution of the number of tourist arrivals in the tourist accommodation structures in the urban area $(\mathrm{Yt})$.

Starting from the data provided by the National Institute of Statistics (INS) it is found that, in the period 2007-2009, the degree of urbanization 
decreased from 1.2446 to 1.1678 , subsequently increasing, in the period 20092012 to 1.1744. Starting with 2013, the degree of urbanization decreases constantly, to a minimum of 1.1426 in 2019.

In the period 2007-2019, the share of modernized roads increased constantly, from $27.25 \%$ to $44.18 \%$ (Chart 1 ).

Chart 1. Evolution of the degree of urbanization and the share of modernized roads in the period 2007-2019

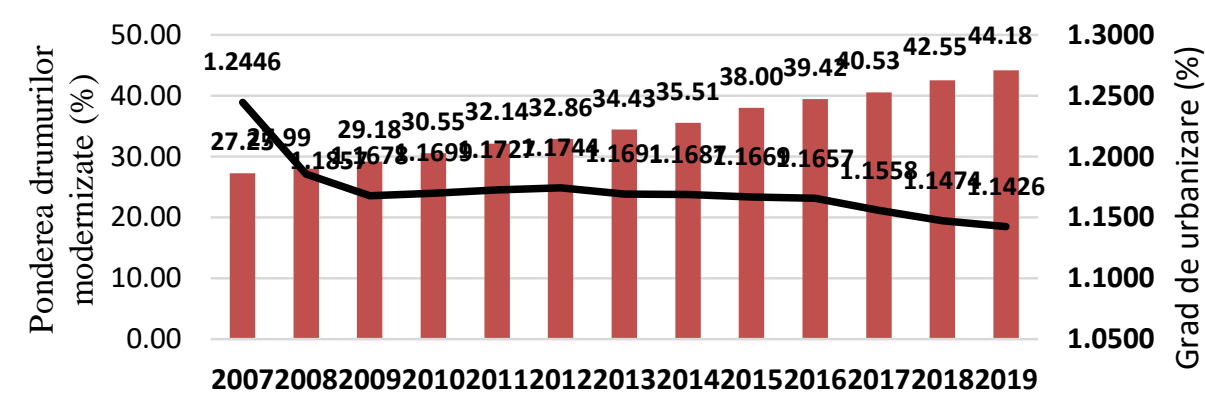

Ponderea drumurilor modernizate (\%) — Grad de urbanizare (\%)

Source: Tempo online database. National Institute of Statistics (NIS) [8].

In the same period, the number of tourists in urban areas increased from 5.934 million people in 2007 to 10.811 million people in 2019 (Table 1).

Table 1. Evolution of the number of tourists in the urban environment, of the percentage of modernized roads and of the degree of urbanization, in Romania, in the interval 2007-2019

\begin{tabular}{|c|c|c|r|}
\hline Year & $\begin{array}{c}\boldsymbol{Y}_{\boldsymbol{t}} \text { (tourist } \\
\text { number } \\
\text { thousands) }\end{array}$ & $\begin{array}{c}\boldsymbol{X}_{\mathbf{1} \boldsymbol{t}} \\
\text { (modernized } \\
\text { roads, } \mathbf{\%})\end{array}$ & $\begin{array}{c}\boldsymbol{X}_{\mathbf{2} \boldsymbol{t}} \text { (urbanization } \\
\text { degree) }\end{array}$ \\
\hline 2007 & $5.934,918$ & 27.248 & 1.244599307 \\
\hline 2008 & $6.004,302$ & 27.989 & 1.185714084 \\
\hline 2009 & $5.153,868$ & 29.184 & 1.16778365 \\
\hline 2010 & $5.179,607$ & 30.552 & 1.169940946 \\
\hline 2011 & $5.992,329$ & 32.137 & 1.172699469 \\
\hline 2012 & $6.498,399$ & 32.862 & 1.174357636 \\
\hline 2013 & $6.671,776$ & 34.431 & 1.169131851 \\
\hline 2014 & $7.107,254$ & 35.508 & 1.168702758 \\
\hline 2015 & $8.388,269$ & 37.998 & 1.166864159 \\
\hline
\end{tabular}


Lumen Proceedings 14 | International Conference IBMAGE 2020

\begin{tabular}{|c|r|r|r|}
\hline 2016 & $9.202,716$ & 39.415 & 1.165741267 \\
\hline 2017 & $10.014,648$ & 40.534 & 1.155802101 \\
\hline 2018 & $10.537,876$ & 42.546 & 1.147429943 \\
\hline 2019 & $10.811,588$ & 44.178 & 1.142587399 \\
\hline Media & 7499,812 & 34.968 & 1.171643 \\
\hline Mediana & 6671,776 & 34.431 & 1.168703 \\
\hline
\end{tabular}

Source: Tempo online database. National Institute of Statistics (NIS) and own calculations based on them. [8]

\section{Research Methods}

In a first stage, we performed an econometric analysis, based on a simple linear regression, and in order to estimate the model we used the least squares method.

The following relationship is considered:

$$
\mathrm{Yt}=\mathrm{a} 0+\mathrm{a} 1 \mathrm{X} 1 \mathrm{t}+\mathrm{a} 2 \mathrm{X} 2 \mathrm{t}+\mathrm{et},(1)
$$

where the variable explained Yt represents the number of tourists in Romania, in the urban environment, estimated by the number of arrivals of tourists in tourist reception structures by types of structures; $a 0$, a1, a2 are real constants, and the explanatory variables X1t, X2t represent the percentage of modernized roads in Romania, respectively the degree of urbanization in Romania expressed as the number of citizens residing in urban areas divided by the number of citizens residing in rural areas.

The residual variable was also denoted by et. This is included in the model, because the endogenous variable is also affected by a number of factors that are not specified in the regression model, for several reasons: the series of variables cannot be measured directly or are not observable, and the data series for other explanatory variables are recorded with significant errors. Therefore, this variable quantifies the influence of other factors, not recorded.

First, it is necessary to test the stationarity of the series. For this purpose, the KPSS test (Kwiatkowski-Phillips-Schmidt-Shin statistical test) is used. If the value of the test is greater than the asymptotic value corresponding to the standard significance threshold of $5 \%$, then the null hypothesis that the series is stationary is rejected.

The test results indicate that the series are not stationary in level (Tables $4,5,6)$. The KPSS test values for the three variables are higher than the asymptotic value of the standard significance threshold of $5 \%$.

After applying the 1 st order differentiation operator, the data series become stationary (Tables $7,8,9)$. However, due to the small number of observations (13 observations), these variables are generally considered stationary. 


\section{Findings}

\subsection{Structure}

\section{- The Urban image must be a part of the program points of the administrations}

The transformation and promotion of the urban image must become one of the main program points of the administrations, so promoting the locations was considered an important objective of urban development, thus being able to promote areas for tourism, but the way to achieve the goal is to a very large variety.

Much of the transformation undergone by Western European industrial cities has involved an investigative marketing process, the development of new facilities and the creation of new landscapes, as well as the promotion of rejuvenated urban images.

The economic rationale behind these efforts has been created by new jobs and attracting tourists and residents in order to replace the former declining manufacturing economies.

Given that tourist attractions in general are mainly in cities, urban infrastructure, investigations as well as cultural facilities, they must be taken into account when designing and calculating the economic impact of urban regeneration.

\section{- Identifying the need to implicate the urban actors}

The city is the physical expression of negotiations between urban actors.

Thus, in this guide the rules of the partnership between the actors within an integrated urban regeneration project were identified, as follows:

- Mutual recognition of the need to work in a team - public administration, professionals, citizens

- Partnership is an arena in which urban actors face visions of city development, discuss and decide on intervention priorities, gather and share resources.

- A partnership is not made overnight, but it is a long process, which requires a lot of patience for building trusting relationships, for understanding the differences between different partners.

\section{- Use of the strategic planification}

It is based on a flexible and integrated model of action, characterized by an ability to adjust the objectives defined by the public administration, in relation to the interests of urban actors and the means available. 
The expansion of cities encompassed industrial areas, their position becoming even central. The restructuring of industries has created impressive areas, large urban reserves that must be used to meet current and future human needs and industrial buildings, currently dysfunctional, that must be integrated into the current landscape.

Historically, the industrial areas appeared during the production-based economy, were triggering factors for the emergence of new functions, markets, new traffic arteries [2].

Currently, these industrial areas, brownfield type areas, which appeared as a result of the deindustrialization process, are non-functional, causing urban decline through the emergence of areas with large areas of urban land not valued for financial reasons or other reasons (political, social etc.) [3].

Table 2. Linear regression

\begin{tabular}{|l|c|c|c|c|}
\hline & Coefficient & Standard Error & Statistics t & Probabilities \\
\hline Constant & -34078.67 & 11689.93 & -2.915215 & 0.01 \\
\hline Modernized Roads & 421.5077 & 39.92738 & 10.55686 & $<0.05$ \\
\hline Urbanization degree & 22907.35 & 9066.705 & 2.526535 & 0.03 \\
\hline & $\begin{array}{c}\text { Number of } \\
\text { observations }\end{array}$ & $R^{2}$ & $R^{2}$ ajustat & $\begin{array}{c}\text { Durbin Watson } \\
\text { Test }\end{array}$ \\
\hline & 13 & 0.94 & 0.93 & 1.167056 \\
\hline
\end{tabular}

Source: Author computation

\subsection{Tables}

The econometric analysis contributes to the general conclusion of this paper by calculating the impact of the quality of road transport infrastructure, expressed by the percentage of modernized roads, the degree of urbanization, expressed as a ratio between the urban population and the rural population, on the development of tourism in Romania. 
Table 3. Linear regression

Dependent Variable: TURIST

Method: Least Squares

Date: 06/12/20 Time: 16:23

Sample (adjusted): 113

Included observations: 13 after adjustments

\begin{tabular}{lrrrr}
\hline \hline \multicolumn{1}{c}{ Variable } & Coefficient & \multicolumn{1}{c}{ Std. Error } & t-Statistic & Prob. \\
\hline \hline \multicolumn{1}{c}{ ROADS } & 421.5077 & 39.92738 & 10.55686 & 0.0000 \\
URBANIZATION & 22907.35 & 9066.705 & 2.526535 & 0.0300 \\
\multicolumn{1}{c}{ C } & -34078.67 & 11689.93 & -2.915215 & 0.0154 \\
\hline \hline R-squared & 0.944907 & Mean dependent var & 7499.812 \\
Adjusted R-squared & 0.933888 & S.D. dependent var & 2039.172 \\
S.E. of regression & 524.3164 & Akaike info criterion & 15.56124 \\
Sum squared resid & 2749077. & Schwarz criterion & 15.69161 \\
Log likelihood & -98.14807 & Hannan-Quinn criter. & 15.53444 \\
F-statistic & 85.75530 & Durbin-Watson stat & 1.167056 \\
Prob(F-statistic) & 0.000001 & & \\
\hline \hline
\end{tabular}

Source: Author computation

Table 4. KPSS test for the dependent variable $Y_{t}$ (levels)

Null Hypothesis: TURISTI is stationary

Exogenous: Constant

Bandwidth: 2 (Newey-West automatic) using Bartlett kernel

LM-Stat.

\begin{tabular}{|c|c|c|}
\hline \multicolumn{2}{|c|}{$\underline{\text { Kwiatkowski-Phillips-Schmidt-Shin test statistic }}$} & 0.490136 \\
\hline Asymptotic critical values*: & $1 \%$ level & 0.739000 \\
\hline & $5 \%$ level & 0.463000 \\
\hline & $10 \%$ level & 0.347000 \\
\hline
\end{tabular}

*Kwiatkowski-Phillips-Schmidt-Shin (1992, Table 1)

Residual variance (no correction)

3838358.

HAC corrected variance (Bartlett kernel)

9488507. 
KPSS Test Equation

Dependent Variable: TURISTI

Method: Least Squares

Date: 06/12/20 Time: 16:34

Sample (adjusted): 113

Included observations: 13 after adjustments

\begin{tabular}{lrlll}
\hline \hline \multicolumn{1}{c}{ Variable } & Coefficient & Std. Error & t-Statistic & Prob. \\
\hline \hline \multicolumn{1}{c}{ C } & 7499.812 & 565.5645 & 13.26075 & 0.0000 \\
\hline \hline R-squared & 0.000000 & Mean dependent var & 7499.812 \\
Adjusted R-squared & 0.000000 & S.D. dependent var & 2039.172 \\
S.E. of regression & 2039.172 & Akaike info criterion & 18.15228 \\
Sum squared resid & 49898657 & Schwarz criterion & 18.19574 \\
Log likelihood & -116.9898 & Hannan-Quinn criter. & 18.14335 \\
Durbin-Watson stat & 0.103756 & & \\
\hline \hline
\end{tabular}

Source: Author computation

Table 5. KPSS test for explanatory variable $\mathbf{X}_{\mathbf{1 t}}$ (levels)

Null Hypothesis: DRUMURI is stationary

Exogenous: Constant

Bandwidth: 2 (Newey-West automatic) using Bartlett kernel

\begin{tabular}{|c|c|c|}
\hline & & LM-Stat. \\
\hline \multicolumn{2}{|c|}{ Kwiatkowski-Phillips-Schmidt-Shin test statistic } & 0.544268 \\
\hline \multirow[t]{3}{*}{ Asymptotic critical values*: } & $1 \%$ level & 0.739000 \\
\hline & $5 \%$ level & 0.463000 \\
\hline & $10 \%$ level & 0.347000 \\
\hline
\end{tabular}

*Kwiatkowski-Phillips-Schmidt-Shin (1992, Table 1)

Residual variance (no correction)

28.95964

HAC corrected variance (Bartlett kernel)

69.26634

KPSS Test Equation

Dependent Variable: DRUMURI

Method: Least Squares

Date: 06/12/20 Time: 16:35 
Sample (adjusted): 113

Included observations: 13 after adjustments

\begin{tabular}{|c|c|c|c|}
\hline Variable & Coefficient & Std. Error t-Statistic & Prob. \\
\hline $\mathrm{C}$ & 34.96793 & $1.553481 \quad 22.50940$ & 0.0000 \\
\hline R-squared & 0.000000 & Mean dependent var & 34.96793 \\
\hline Adjusted R-squared & 0.000000 & S.D. dependent var & 5.601156 \\
\hline S.E. of regression & 5.601156 & Akaike info criterion & 6.357626 \\
\hline Sum squared resid & 376.4753 & Schwarz criterion & 6.401084 \\
\hline Log likelihood & -40.32457 & Hannan-Quinn criter. & 6.348694 \\
\hline $\begin{array}{l}\text { Durbin-Watson } \\
\text { stat }\end{array}$ & 0.070864 & & \\
\hline
\end{tabular}

Source: Author computation

Table 6. KPSS test for the explanatory variable $X_{2 t}$ (levels)

Null Hypothesis: URBANIZATION is stationary

Exogenous: Constant

Bandwidth: 1 (Newey-West automatic) using Bartlett kernel

LM-Stat.

\begin{tabular}{|c|c|c|}
\hline \multicolumn{2}{|c|}{ Kwiatkowski-Phillips-Schmidt-Shin test statistic } & 0.548912 \\
\hline \multirow{3}{*}{ Asymptotic critical values*: } & $1 \%$ level & 0.739000 \\
\hline & $5 \%$ level & 0.463000 \\
\hline & $10 \%$ level & 0.347000 \\
\hline \multicolumn{3}{|c|}{ *Kwiatkowski-Phillips-Schmidt-Shin (1992, Table 1) } \\
\hline \multirow{2}{*}{\multicolumn{2}{|c|}{$\begin{array}{l}\text { Residual variance (no correction) } \\
\text { HAC corrected variance (Bartlett kernel) }\end{array}$}} & 0.000562 \\
\hline & & 0.000731 \\
\hline
\end{tabular}

KPSS Test Equation

Dependent Variable: URBANIZATION

Method: Least Squares

Date: 06/12/20 Time: 16:37

Sample (adjusted): 113

Included observations: 13 after adjustments

\begin{tabular}{|c|c|c|c|c|}
\hline Variable & Coefficient & Std. Error & t-Statistic & Prob. \\
\hline $\mathrm{C}$ & 1.171643 & 0.006841 & 171.2647 & 0.0000 \\
\hline
\end{tabular}




\begin{tabular}{lllr}
\hline \hline R-squared & 0.000000 & Mean dependent var & 1.171643 \\
Adjusted R-squared & 0.000000 & S.D. dependent var & 0.024666 \\
S.E. of regression & 0.024666 & Akaike info criterion & -4.492977 \\
Sum squared resid & 0.007301 & Schwarz criterion & -4.449520 \\
Log likelihood & 30.20435 & Hannan-Quinn criter. & -4.501910 \\
Durbin-Watson stat & 0.551770 & & \\
\hline \hline
\end{tabular}

Source: Author computation

First, it is necessary to test the stationarity of the series. For this purpose, the KPSS test (Kwiatkowski-Phillips-Schmidt-Shin statistical test) is used. If the value of the test is greater than the asymptotic value corresponding to the standard significance threshold of $5 \%$, then the null hypothesis that the series is stationary is rejected.

The test results indicate that the series are not stationary in level (Tables $4,5,6)$. The KPSS test values for the three variables are higher than the asymptotic value of the standard significance threshold of 5\%.

Regarding the normality of the residues, the probability of the JarqueBera test $(p \sim 0.38)$ is higher than the 5\% threshold, therefore, the null hypothesis is not rejected (the residues are normally distributed).

At the same time, the hypothesis of homoskedasticity is respected. Based on the White test, its probability $(\mathrm{p}=0.07)$ is higher than the $5 \%$ confidence interval and therefore H_0 is not rejected.

Regarding the multicollinearity within the explanatory variables, this is not manifested in the presented model. For this purpose, the VIF results are analyzed, for the explanatory variables, and compared with the value 4 . Both values are lower than the reference level, so there is no problem of multicollinearity.

\section{Discussions}

To achieve the goals, the traditional approach to urban planning needs to be replaced by integrated care that imports more factors and actors into the urban scene. The task of the national government is to ensure that these objectives are met through local initiatives and to encourage local authorities by providing a more effective urban planning mechanism, from a legislative point of view, as well as the necessary funds.

From the studied model it results that, the value of the test is higher than the asymptotic value corresponding to the standard significance threshold of $5 \%$, then the null hypothesis is rejected, according to which the series is stationary. 
It is observed that the KPSS test values, for the three variables, are higher than the asymptotic value of the standard significance threshold of $5 \%$, but after the application of the 1 st order differentiation operator, the data series become stationary.

Regarding the normality of the residues, the probability of the JarqueBera test $(\mathrm{p} \sim 0.38)$ is higher than the $5 \%$ threshold, therefore, the null hypothesis is not rejected (the residues are normally distributed.

At the same time, the hypothesis of homoskedasticity is respected. Based on the White test, its probability $(\mathrm{p}=0.07)$ is higher than the $5 \%$ confidence interval and therefore $\mathrm{H} 0$ is not rejected.

Regarding the multicollinearity within the explanatory variables, in order to be able to be studied considering that it does not manifest in the presented model, the results of VIF were analysed, for the explanatory variables, and compared with the value 4 . Both values are lower than the level reference, so there is no problem of multicollinearity.

Regarding the residues, respectively whether they are correlated or not, it resulted from the LM Breusch-Godfrey Test, that the errors are not autocorrelated, in other words, the probability of the test $(p=0.2149)$ is higher than the $5 \%$ threshold.

The probabilities related to the Student $\mathrm{t}$ test are lower than 0.05 corresponding to the significance threshold of $5 \%$ suggesting a significant relationship between the dynamics of the number of tourists in the urban area and the dynamics of the percentage of modernized roads, but also between the dynamics of the number of tourists in the urban area.

\section{Conclusions}

From the studied model it results that, the value of the test is higher than the asymptotic value corresponding to the standard significance threshold of $5 \%$, then the null hypothesis is rejected, according to which the series is stationary.

The probabilities studied are suggesting a significant relationship between the dynamics of the number of tourists in the urban area and the dynamics of the percentage of modernized roads, but also between the dynamics of the number of tourists in the urban area.

Romanian cities, regardless of the size of the power, must focus efforts to rehabilitate the historic areas, therefore, they can be historical and cultural heritage. Moreover, using a residential area in the area (with special attention to the neighbourhood of blocks of flats) must simultaneously strengthen with public space refurbishment spaces, such as squares, parks, street furniture and 
the like. For a positive result, urban infrastructure must also be modernized, in line with European standards.

\section{References}

[1] Alpopi C, Manole C. Integrated Urban Regeneration - Solution for Cities Revitalize. Procedia Economics and Finance. 2013;6:178 - 185.

[2] Ioan-Franc V, Ristea A-L, et al. Dotările comerciale şi regenerarea urbană. Contribuția activității comerciale la dezvoltarea durabilă. Bucuresti: Amfiteatru Economic; 2010.

[3] Ioan-Franc V, Ristea A-L, Popescu C. Integrated Urban Governance: A New Paradigm of Urban Economy. 2nd International Conference "Economic Scientific Research - Theoretical, Empirical and Practical Approaches". ESPERA 2014. 13-14 November 2014. Bucharest. Romania.

[4] Marra G, Barosio M, Eynard E, Marietta C. From urban renewal to urban regeneration: Classification criteria for urban interventions. Turin 1995-2015: evolution of planning tools and approaches. Journal of Urban Regeneration and Renewal [Internet]. 2016;9(4):367-380. Available from: https://www.researchgate.net/publication/310445787 From urban renewal to urban regeneration Classification criteria for urban interventions Turin 199 5-2015 Evolution of planning tools and approaches

[5] Moldoveanu M, Ioan-Franc V. Urban regeneration and more opportunities for artistic expression and cultural consumption. Procedia Economics and Finance. 2014;8:490 - 496.

[6] Nae M. Regenerarea şi reconversia teritoriilor. Editura Universitară; 2015.

[7] Roberts P, Sykes H, Granger R. Urban Regeneration - The evolution, definition and purpose of Urban Regeneration. Journal of Urban Regeneration and Renewal. 2016;9(4):367-380.

[8] Indicatori_de_dezvoltare_durabila_nivel_national [nternet]. Available from: https://insse.ro/cms/files/Web_IDD_BD_ro/index.htm

[9] Spatial development glossary. European Conference of Ministers responsible for Spatial/Regional Planning (CEMAT). Territory and landscape. No. 2. Council of Europe Publishing; 2007.

[10] Sustainable development strategies and indicators Romania [nternet]. Available from: http://sdgtoolkit.org/wp-content/uploads/2019/10/RomaniasSustainable-Development-Strategy-2030.pdf

[11] Toledo Declaration on Urban Development [Internet]. 2010. Available from: https://www.mlpda.ro/userfiles/declaratie Toledo_ro.pdf 